\title{
The Southern Glacial Maximum 65,000 years ago and its Unfinished Termination
}

\author{
Joerg M. Schaefer a, b, *, Aaron E. Putnam a , George H. Denton ' , Michael R. Kaplan a, \\ Sean Birkel ${ }^{\text {, }}$, Alice M. Doughty ${ }^{\mathrm{d}, 1}$, Sam Kelley ${ }^{\mathrm{e}, 2}$, David J.A. Barrell ${ }^{\mathrm{f}}$, Robert C. Finkel ${ }^{\mathrm{g}}$, \\ Gisela Winckler $^{\mathrm{a}, \mathrm{b}}$, Robert F. Anderson ${ }^{\mathrm{a}, \mathrm{b}}$, Ulysses S. Ninneman ${ }^{\mathrm{h}}$, Stephen Barker ${ }^{\mathrm{i}}$, \\ Roseanne Schwartz ${ }^{\mathrm{a}}$, Bjorn G. Andersen ${ }^{\mathrm{j}, 3}$, Christian Schluechter $^{\mathrm{k}}$ \\ a Lamont-Doherty Earth Observatory, Geochemistry, Palisades, NY 10964, USA \\ b Columbia University, Department of Earth and Environmental Sciences, New York, NY 10027, USA \\ ${ }^{\mathrm{c}}$ University of Maine, Department of Earth Sciences and Climate Change Institute, Orono, ME 04469, USA \\ d Victoria University of Wellington, 6140 Wellington, New Zealand \\ e SUNY Buffalo, Department of Geology, Buffalo, NY 14260, USA \\ ${ }^{\mathrm{f}}$ GNS Science, Dunedin, New Zealand \\ g University of California, Berkeley, Department of Earth and Planetary Sciences, Berkeley, CA 95064, USA \\ ${ }^{\mathrm{h}}$ University of Bergen, Department of Earth Sciences, N-500 Bergen, Norway \\ ${ }^{\mathrm{i}}$ Cardiff University, School of Earth and Ocean Sciences, Cardiff CF10 3AT, United Kingdom \\ ${ }^{\mathrm{j}}$ University of Oslo, Department of Geology, 0316 Oslo, Norway \\ ${ }^{\mathrm{k}}$ Institute for Geological Sciences and Oeschger Center for Climate Change Research, Universität Bern, CH-3012 Bern, Switzerland
}

\section{A R T I C L E I N F O}

\section{Article history:}

Received 29 April 2014

Received in revised form

8 February 2015

Accepted 9 February 2015

Available online

\section{Keywords:}

Ice ages

Terminations

Marine Isotope Stage 4

Paleoclimate

Last Glacial Maximum

Moraines

Surface exposure dating

Cosmogenic nuclides

\begin{abstract}
A B S T R A C T
Glacial maxima and their terminations provide key insights into inter-hemispheric climate dynamics and the coupling of atmosphere, surface and deep ocean, hydrology, and cryosphere, which is fundamental for evaluating the robustness of earth's climate in view of ongoing climate change. The Last Glacial Maximum (LGM, 26-19 ka ago) is widely seen as the global cold peak during the last glacial cycle, and its transition to the Holocene interglacial, dubbed 'Termination 1 (T1)', as the most dramatic climate reorganization during this interval. Climate records show that over the last $800 \mathrm{ka}$, ice ages peaked and terminated on average every $100 \mathrm{ka}$ ('100 ka world'). However, the mechanisms pacing glacial-interglacial transitions remain controversial and in particular the hemispheric manifestations and underlying orbital to regional driving forces of glacial maxima and subsequent terminations remain poorly understood.

Here we show evidence for a full glacial maximum in the Southern Hemisphere $65.1 \pm 2.7$ ka ago and its 'Unfinished Termination'. Our ${ }^{10} \mathrm{Be}$ chronology combined with a model simulation demonstrates that New Zealand's glaciers reached their maximum position of the last glacial cycle during Marine Isotope Stage-4 (MIS-4). Southern ocean and greenhouse gas records indicate coeval peak glacial conditions, making the case for the Southern Glacial Maximum about halfway through the last glacial cycle and only $15 \mathrm{ka}$ after the last warm period (MIS-5a). We present the hypothesis that subsequently, driven by boreal summer insolation forcing, a termination began but remained unfinished, possibly because the northern ice sheets were only moderately large and could not supply enough meltwater to the North Atlantic through Heinrich Stadial 6 to drive a full termination. Yet the Unfinished Termination left behind substantial ice on the northern continents (about $50 \%$ of the full LGM ice volume) and after another $45 \mathrm{ka}$ of cooling and ice sheet growth the earth was at inter-hemispheric Last Glacial Maximum configuration, when similar orbital forcing hit maximum-size northern ice sheets and ushered in $\mathrm{T} 1$ and thus the ongoing interglacial. This argument highlights the critical role of full glacial conditions in both
\end{abstract}

\footnotetext{
* Corresponding author. Lamont-Doherty Earth Observatory, Geochemistry, Palisades, NY 10964, USA.

E-mail address: Schaefer@ldeo.columbia.edu (J.M. Schaefer).

1 Now at: Dartmouth College, Department of Earth Sciences, Hanover, NH 03755, USA.

2 Now at: University of Waterloo, Department of Earth and Environmental Sciences, Waterloo, Ontario N2L 3G1, Canada.

3 Deceased.
} 
hemispheres for terminations and implies that the Southern Hemisphere climate could transition from interglacial to full glacial conditions in about 15,000 years, while the Northern Hemisphere and its continental ice-sheets required half a glacial cycle.

๑) 2015 Elsevier Ltd. All rights reserved.

\section{Introduction}

Termination 1 (T1), began about $19 \mathrm{ka}$ ago and transitioned the earth from the global Last Glacial Maximum (LGM; 26 -19 ka ago) of Marine Isotope Stage-2 (MIS-2; 26-11.5 ka ago) to the ongoing Holocene interglacial. Important progress in understanding the climate events leading into global glacial maxima and through terminations has been made recently (Barker et al., 2009; Cheng et al., 2009; Clark et al., 2009; Denton et al., 2010). However, theories proposing the Northern Hemisphere and the maximum size of the continental ice-sheets during the LGM to be of critical importance for terminations (Denton and Hughes, 1981; Raymo, 1997; Abe-Ouchi et al., 2013), face opposing scenarios that assign the leading role in glacial-interglacial transitions to Southern Hemisphere drivers (for example WAIS Divide Project Members (2013); Wolff et al. (2006)).

Moreover, other basic questions remain, such as why the durations of mid-to late Pleistocene glacial cycles varied between $80 \mathrm{ka}$ and $120 \mathrm{ka}$ (Huybers and Wunsch, 2005) and why even prominent climate transitions during glacials have failed to end ice ages (Barker et al., 2009). Here we provide new evidence addressing these problems, based on the first comprehensive chronology and modeling of mountain glaciers in New Zealand's Southern Alps during MIS-4.

The MIS-4 cold period (74-59 ka ago) and its transition to the MIS-3 mild period (59- 26 ka ago) are recorded in polar ice cores (EPICA community members, 2004), marine sediments (Chapman and Shackleton, 1998; Kaiser and Lamy, 2010) and speleothems (Wang et al., 2001). However, direct terrestrial evidence and chronologies for glacier and ice-sheet response during these periods remain sparse and controversial (see Supplementary Discussion), in part because MIS- 4 is beyond the radiocarbon time-scale. We date and quantify the response of southern middlelatitude summer temperature sensitive mountain glaciers to the MIS-4 cold period and evaluate the response of the cryosphere-atmosphere-ocean system to the transition towards the warmer MIS-3 climate. With the goal to highlight key drivers of terminations, we then compare the MIS-4/3 transition with the inter-hemispheric MIS-2 LGM and the subsequent T1.

\section{Geomorphic setting, methods and analysis}

\subsection{Glaciers and climate}

Mountain glaciers in New Zealand's Southern Alps are particularly sensitive recorders of atmospheric change and respond on the centennial and millennial scale primarily to summer temperature variations (Oerlemans, 2005; Anderson and Mackintosh, 2006; Anderson et al., 2010). We interpret our glacial-geological record accordingly.

\subsection{Moraines}

Outboard of the LGM moraines fringing Lakes Pukaki and Tekapo, are topographically more subdued moraines named 'Balmoral' (green in Fig. 1) as described in detail by Barrell (2014), making New Zealand's Southern Alps one of the few locations where such glacial landforms have not been destroyed by LGM glaciers and related outwash floods (Burrows, 2005; Barrell, 2014). The particularly prominent and well-preserved Balmoral moraine belt fringing Lake Pukaki attests to a full-glacial cold period in New Zealand prior to the MIS-2 LGM (Fig. 1).

\subsection{Samples}

Numerous large greywacke boulders occur embedded in moraine ridges or ground moraine within the Balmoral moraine belts were the targets of our ${ }^{10} \mathrm{Be}$ surface exposure dating program. We focused on sampling the top $2 \mathrm{~cm}$ of flat rock surfaces. The quartzo-feldspathic greywacke lithology is very resistant to erosion, which is mirrored by the surprisingly high internal consistency of the boulder ages (Fig. 1, Supplementary Fig. 2).

We sampled and dated a total of 60 moraine boulders (Fig. 1; Supplementary Table 1): 48 boulders from the Lake Pukaki Balmoral moraines, 2 boulders from the Lake Tekapo Balmoral moraines, and for context, 10 from the Lake Pukaki LGM moraines, extending an earlier chronology (Schaefer et al., 2006). In order to date the Balmoral glacier culmination, we focused particularly on boulders from the outermost Balmoral moraine ridges at Lake Pukaki. We sampled 6 boulders from outer and 3 from the inner moraine segments of the well-preserved left-lateral Maryburn lobe area (Barrell, 2014). In the less-well-preserved terminal, left and right lateral moraines, we sampled 33 boulders on the outer remnants of the Balmoral moraine ridges (Fig. 1) and 6 boulders forming a transect of the inner Balmoral moraines. From the total of 39 boulders from outermost moraines, we include 36 ages in our final age determination of the Balmoral glacier culmination (3 young outliers excluded; see Fig. 1b). The 9 samples from the inner moraine segments yield generally consistent, and chronologically similar, results (Supplementary Fig. 2). We also present the ages of two samples from Balmoral moraines of the adjacent Lake Tekapo glacial trough (Fig. 1).

\subsection{Geochemistry and AMS analysis}

All samples were processed at the cosmogenic dating laboratory of the Lamont-Doherty Earth Observatory, the ${ }^{10} \mathrm{Be} /{ }^{9} \mathrm{Be}$ analyses were performed at the Center for Accelerator Mass Spectrometry (CAMS) at the Lawrence Livermore National Laboratory. We applied standard techniques (Schaefer et al., 2009) to separate and decontaminate quartz from the whole-rock greywacke samples (http://www.ldeo.columbia.edu/res/pi/tcn/LDEO_Cosmogenic_ Nuclide_Lab/Chemistry.html) and standard isotope dilution methods.

${ }^{9}$ Be currents for our samples ranged from 16 to $26 \mu \mathrm{A}$. Individual AMS sample targets were measured during 2-6 runs at 5 min each, providing high counting statistics and an internal control of the stability of the AMS. The data show $1 \sigma$ analytical error ranging from $1.4 \%$ to $5.0 \%$, with an average of $2.5 \%$. Overall background corrections, including boron correction, correction for process blank, and sensitivity variations of the AMS during analysis were below $1 \%$ for all samples. 


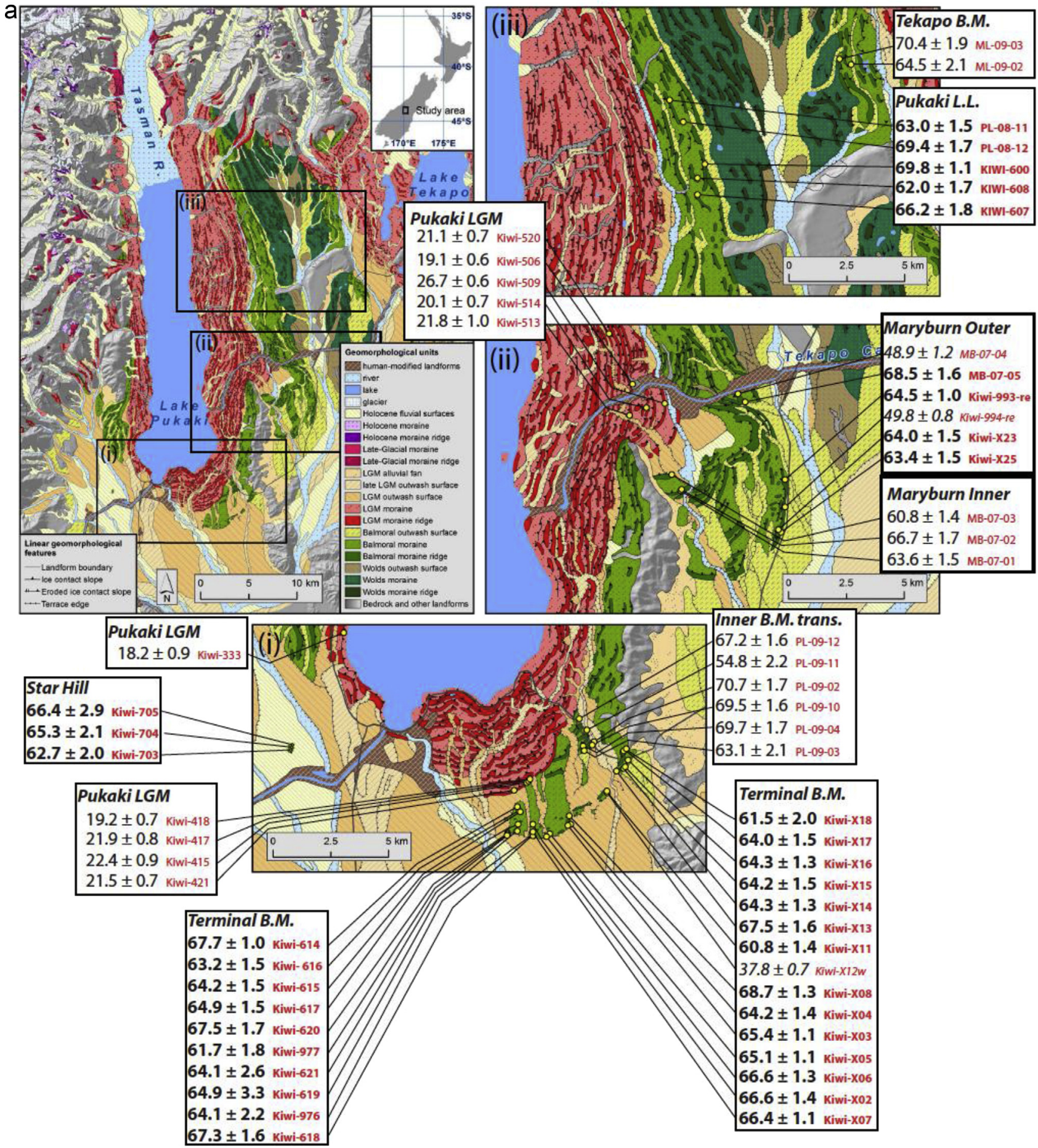

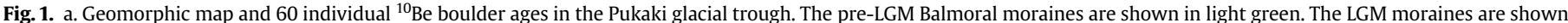

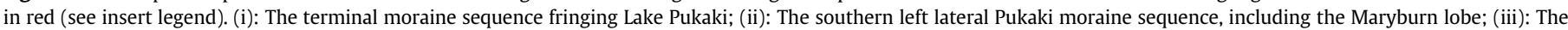

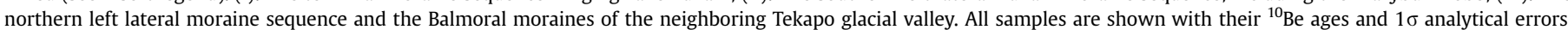

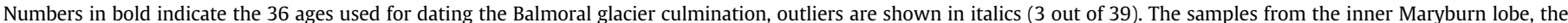

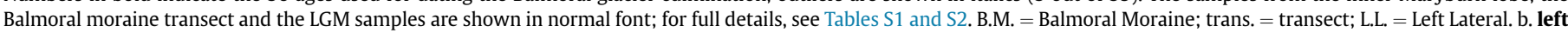

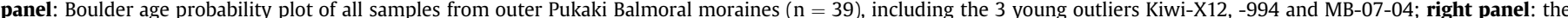

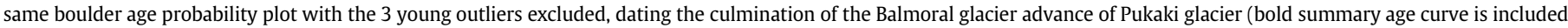

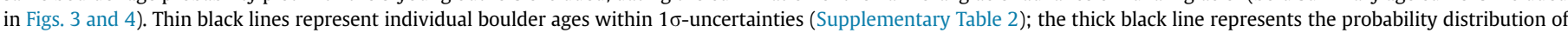

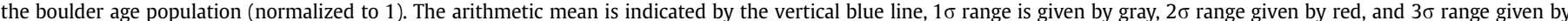

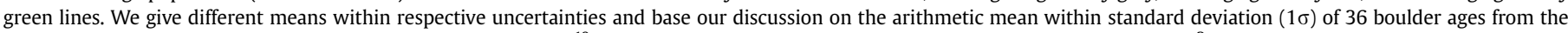

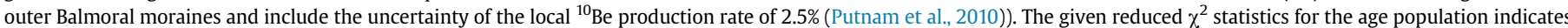

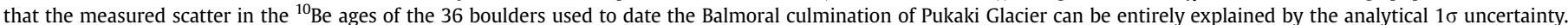




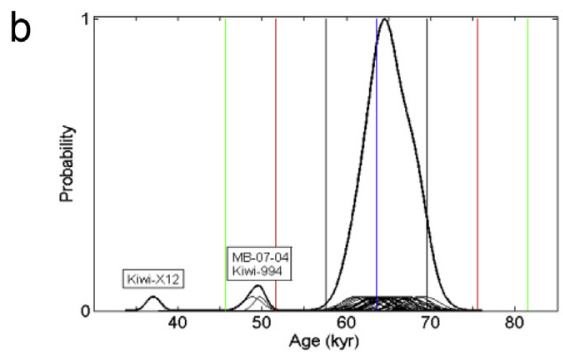

$N=39$

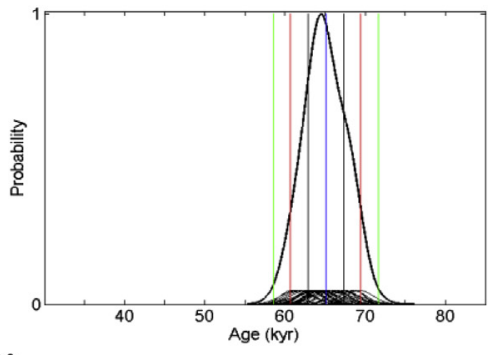

$\mathbf{N}=36$

Arithmetic mean/1 sigma uncertainty: $65,090 \pm 2,190 \mathrm{yrs}$ Including production rate uncertainty: $\underline{65,090 \pm 2,730 \mathrm{yrs}}$

Weighted mean/weighted uncertainty: $65,340 \pm 240 \mathrm{yrs}$ Peak Age: $\quad 64,510 \mathrm{yrs}$

Median/Interquartile Range: $\quad 64,680 \pm 2,630 \mathrm{yrs}$ Reduced $\chi^{2}$ :

Fig. 1. (continued).

\subsection{Production rates}

We used a local ${ }^{10} \mathrm{Be}$ production rate calibration (Putnam et al., 2010), defined in Macaulay valley, only some $50 \mathrm{~km}$ away and on similar altitude, for the past $\sim 10 \mathrm{ka}$, and corroborated by a ${ }^{10} \mathrm{Be}$ production rate constraint based on LGM moraines fringing Lake Pukaki that were indipendently dated to $\sim 18 \mathrm{ka}$. The concordance of the ${ }^{10} \mathrm{Be}$ rate calibrated for the last $10 \mathrm{ka}$ and that for the last $18 \mathrm{ka}$ indicates that changes in the geomagnetic field strength, which are small during the last $10 \mathrm{ka}$ but substantial between $10 \mathrm{ka}$ and $18 \mathrm{ka}$ ago, do not impact the ${ }^{10}$ Be production to a measurable extent at $44^{\circ} \mathrm{S}$ and low altitude. This supports earlier numerical calculations showing robustness of time-integrated ${ }^{10} \mathrm{Be}$ production at latitudes of $40^{\circ}$ and higher over the last glacial cycle (Masarik et al., 2001). Together, these findings imply that geomagnetic field changes have minor impact on the ${ }^{10} \mathrm{Be}$ production rate in New Zealand and that the local ${ }^{10} \mathrm{Be}$ production rate (Putnam et al., 2010) is also valid for the longer periods of exposure discussed here. Further, the high internal consistency of the Balmoral boulder ages indicates that potentially compromising effects such as erosion or seasonal snow cover of the boulder surfaces have been negligible (Supplementary Discussion). Detailed assessment of the tectonic uplift in our field area indicates that the influence on cosmogenic nuclide production is minor (Supplementary Discussion and Putnam et al. (2010)). Use of a local ${ }^{10} \mathrm{Be}$ production rate means that the choice of scaling protocol is not critical. We base our discussion on the widely used 'Lm' scaling ((Lal, 1991; Stone, 2000; Balco et al., 2008); Supplementary Table 2).

\subsection{Numerical modeling of the Balmoral glacial event}

By reconstructing the geometry of the Pukaki glacier when it lay at the position of the outermost mapped Balmoral moraines (Fig. 1), Porter (1975) calculated in his pioneering work an equilibrium-line altitude (ELA) depressed $1050 \mathrm{~m}$ below the late 20th century value.

Here, we apply the University of Maine Ice Sheet Model (UMISM), a 2D finite-element mass and momentum ice dynamics solver with embedded components for calculating isostasy, thermodynamics, sliding, and surface mass balance (Fastook and Prentice, 1994; Fastook et al., 2008), and constrained it to mapped and dated Balmoral moraines in order to derive underlying climate and snowline parameters. A similar modeling approach determined the summer temperature cooling during the LGM in the adjacent Lake Ohau catchment to $6.25 \pm 0.5{ }^{\circ} \mathrm{C}$ (Putnam et al., 2013), which agrees with an independent modeling study of the LGM glaciers and related climate changes for the entire Southern
Alps, proposing a LGM cooling of at least $6-6.5^{\circ} \mathrm{C}$ (Golledge et al., 2012).

Our model setup includes a $1 \mathrm{~km}$ gridded climatology derived from the WorldClim dataset (Hijmans et al., 2005), and a degreeday-based mass balance with an atmospheric lapse rate $\left(5{ }^{\circ} \mathrm{C} \mathrm{km}^{-1}\right.$ ) and snow/ice melt rates (4.6 and $7.2 \mathrm{~mm}$ melting degree $^{-1}$ ) measured for New Zealand (Norton, 1985; Anderson et al., 2006). We expanded the previous $0.5 \mathrm{~km}$-gridded Ohau model domain (derived from modern SRTM topography) given in Putnam et al. (2013) to include the Pukaki and Tekapo catchments (Fig. 2). Our tests include a series of 5000-year equilibrium experiments with temperature lowered systematically until modeled ice margins reached Balmoral moraine belts within all three glacial troughs, with particular emphasis on obtaining a close match to mapped ice limits of the Pukaki trough. For simplicity, precipitation was held at $100 \%$ modern, but we acknowledge the possibility of a slightly drier climate over South Island during major glaciations (Drost et al., 2007; Golledge et al., 2012).

\section{Results}

Our geomorphic map and glacier chronology of the Balmoral moraines together with the new LGM dates are shown in Fig. 1, Supplementary Fig. 2 and Supplementary Table 2. The ${ }^{10} \mathrm{Be}$ data from the outermost Balmoral ridges ( $\mathrm{n}=39$; 3 outliers) show high internal consistency, ranging from 61 to $69 \mathrm{ka}$, dating the Balmoral glacier culmination to $65.1 \pm 2.7 \mathrm{ka}$ ago (Fig. 1b). The ${ }^{10} \mathrm{Be}$ ages from boulders from the inner moraines $(n=9)$ agree with this culmination date. Two samples collected from Balmoral moraines deposited by the glacier that expanded through nearby Lake Tekapo yield comparable ages of $63.5 \pm 2.1 \mathrm{ka}$ and $70.4 \pm 1.9 \mathrm{ka}$. This ${ }^{10} \mathrm{Be}$ chronology shows robustly that the Balmoral moraines in New Zealand's Southern Alps were deposited during MIS-4. The 10 boulder ages from LGM moraines range from 18 to $27 \mathrm{ka}$ ago, complementing earlier studies (Schaefer et al., 2006; Putnam et al., 2013; Kelley et al., 2014).

Our model results shown in Fig. 2 indicate that a favorable Balmoral reconstruction, in which ice remains very near mapped geomorphic targets, is attained under a temperature depression of $7{ }^{\circ} \mathrm{C}$ relative to modern conditions. This is $0.75{ }^{\circ} \mathrm{C}$ cooler than the MIS-2 LGM mean temperature estimate for the Ohau catchment simulated with a similar model (Putnam et al., 2013). However, we take the conservative view that this model result simply indicates the existence of a climate regime very similar to full LGM conditions during formation of the Balmoral moraines (see Supplementary Discussion). 

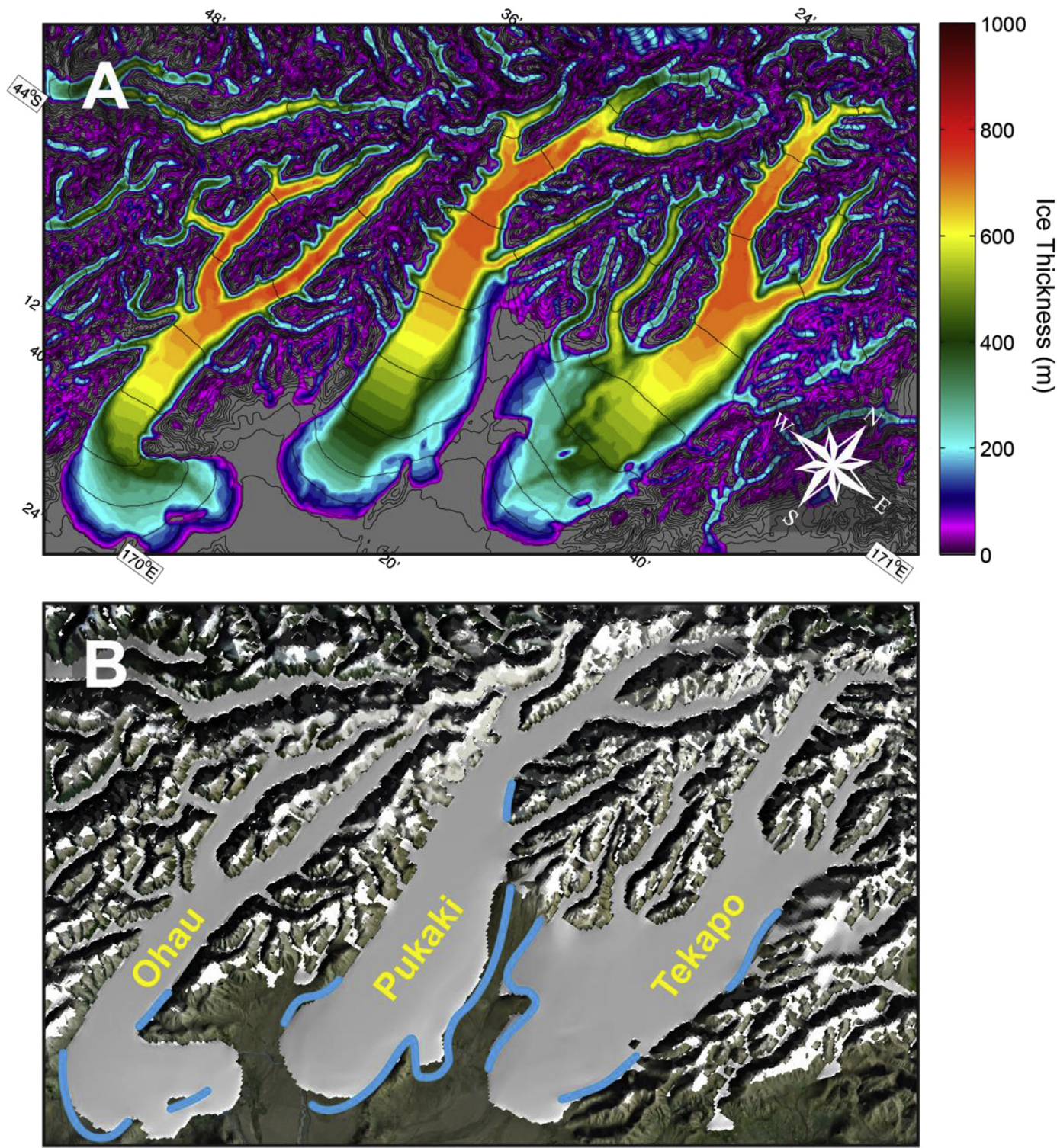

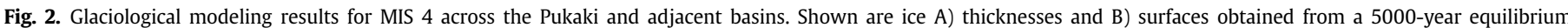
simulation with temperature depressed $7{ }^{\circ} \mathrm{C}$ below modern climatology. Blue lines delineate the mapped outer limit of Balmoral moraines.

Glacial geomorphic mapping, chronology and modeling results together support the conclusion that the most extensive glacier advance of the last glacial cycle in New Zealand's Southern Alps culminated about $65 \mathrm{ka}$ ago, and that this MIS-4 Balmoral glacier maximum represents similar climate conditions to those during the LGM of MIS-2.

\section{Discussion}

The terrestrial signature of maximum size glaciers $65 \mathrm{ka}$ ago is widely supported by complementary climate records from New Zealand (Williams et al., 2015) and the wider Southern Hemisphere (Fig. 3). Sea-surface temperature records off New Zealand, Australia, in the Cape Basin (Pahnke and Sachs, 2006; Barker and Diz, 2014), and off Chile (Kaiser and Lamy, 2010), together with independent proxies of Southern Ocean (SO) stratification (Ninnemann and Charles, 1997; Robinson et al., 2007) and deep SO temperature (Elderfield et al., 2010), indicate a SO in full glacial conditions during the peak of MIS-4, concomitant with New
Zealand's glacier culmination. Dust fluxes to Antarctica (Lambert et al., 2008) and the SO (Martinez-Garcia et al., 2011), proxies of glacier activity in Patagonia (Sugden et al., 2009; Kaiser and Lamy, 2010), show MIS-4 levels consistent with the LGM. SO sea ice extent achieved LGM levels about 65 ka ago, indicated by sea salt sodium fluxes to Antarctica (Wolff et al., 2006). Taken together, these records indicate peak glacial conditions on the continents and surface oceans in southern latitudes during MIS-4, consistent with atmospheric $\mathrm{CO}_{2}$ levels approaching the MIS-2 LGM level of $\sim 185 \mathrm{ppmV}$ (Fig. 3).

The subsequent climate transition to MIS-3 involved major changes of atmosphere, surface ocean and cryosphere (Figs. 3 and 4). Eustatic sea level rose $>30 \mathrm{~m}$ between $\sim 63 \mathrm{ka}$ and $59 \mathrm{ka}$ ago ( $10 \mathrm{~m} / \mathrm{ka}$ sea level rise (Siddall et al., 2003), driven by melting continental ice-sheets. Antarctic dust fluxes decreased markedly, implying glacier recession in Patagonia (Sugden et al., 2009). Atmospheric $\mathrm{CO}_{2}$ levels began to rise in parallel with SO destratification (Ninnemann and Charles, 1997; Robinson et al., 2007), probably the result of increased upwelling of $\mathrm{CO}_{2}$-rich deeper SO 


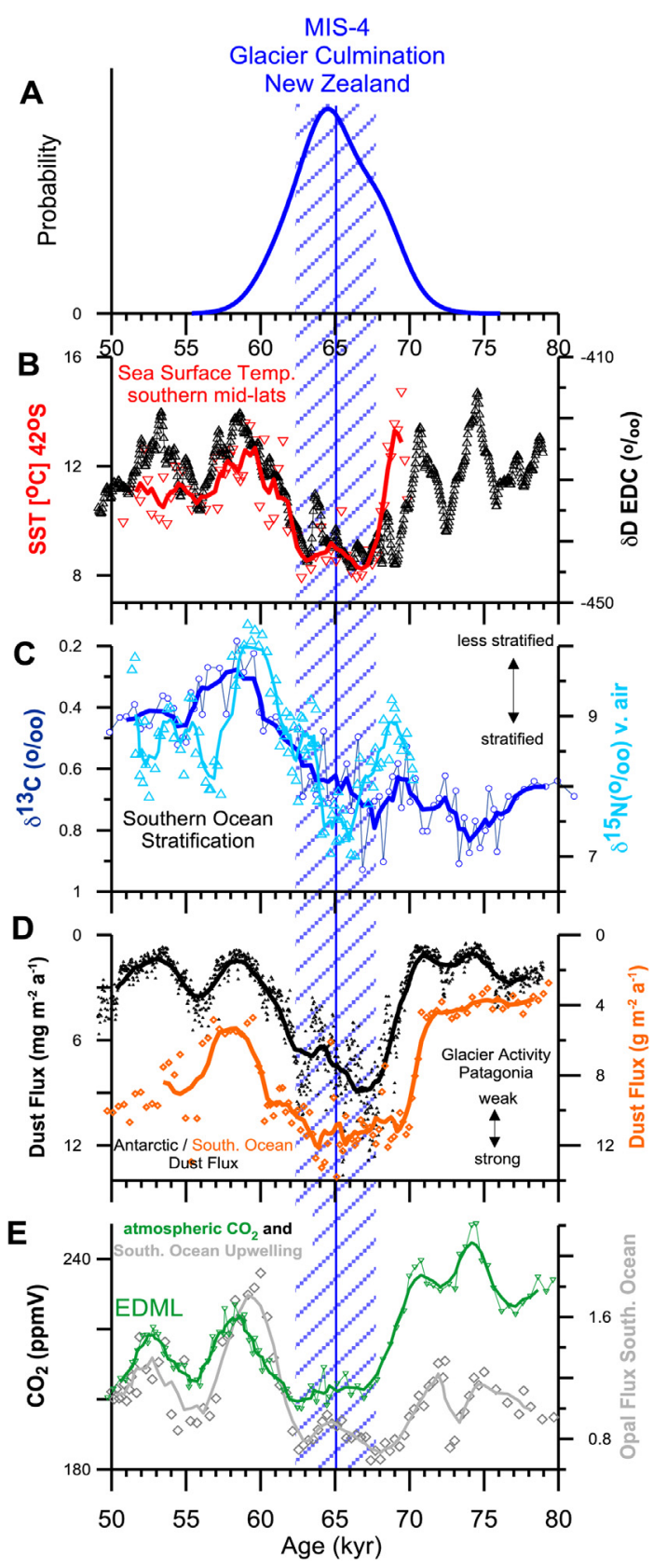

Fig. 3. Southern Hemisphere records of the MIS- 4 period and the MIS- $4 / 3$ transition. A: Probability plot of the age of the glacier culmination in New Zealand (arithm. mean and standard deviation: $65.1 \pm 2.7 \mathrm{ka}$; Supplementary Fig. 2); B: Southern Ocean alkenone-based sea surface temperature records from offshore Chile (Kaiser and Lamy, 2010) and deuterium-inferred Antarctic temperature (EPICA community members, 2004); C: Two independent Southern Ocean stratification records based on nitrogen (Robinson et al., 2007) and carbon isotopes (Ninnemann and Charles, 1997) from southeast Pacific sediments; D: Antarctic (Lambert et al., 2008) and southern ocean (Martinez-Garcia et al., 2011) dust fluxes (y-axis inverted); E: Atmospheric $\mathrm{CO}_{2}$ from the EDML Antarctic ice core (Bereiter et al., 2012) and Southern Ocean upwelling strength derived from opal fluxes in Southern Ocean sediments (Anderson et al., 2009), based on an alternative age model (see Supplementary Fig. 1).

water (Anderson et al., 2009). Even dust fluxes to the equatorial Pacific began to drop from nearly full-stadial level (Winckler et al., 2008).

In Fig. 4, we directly compare the two glacial maxima of the last glacial-interglacial cycle and the subsequent major climate transitions, T1 and the MIS-4/3 transition, addressing the question why $\mathrm{T} 1$ culminated in full and sustained interglacial warmth while the
MIS-4/3 transition stalled in a mild interstadial state, before slipping back towards glacial conditions.

Both transitions display striking consistencies: Orbital forcing represented by increasing boreal summer insolation was equally strong $\left(38 \mathrm{~W} / \mathrm{m}^{2}\right.$ increase between 70 and $58 \mathrm{ka}$ and $40 \mathrm{~W} / \mathrm{m}^{2}$ between 21 and $12 \mathrm{ka}$ ). Both transitions were accompanied by the onset of major Heinrich Stadials (HS), multi-millennial periods of extreme cold in the North Atlantic region, associated with pulses of icebergs and meltwater from decaying northern ice sheets (HS-6 and -1 , respectively). Several millennia later, an abrupt change to much warmer North Atlantic temperatures terminated each HS. The Intertropical Convergence Zone (ITCZ), which is related to the earth's thermal equator, migrated southwards during both HS-6 and HS-1 (Deplazes et al., 2013), and then abruptly shifted northward at their end. Likewise, Chinese monsoon intensity weakened during, and abruptly increased after, HS-6 and HS-1 (Wang et al., 2001).

However, Fig. 4 also displays the few quantitative key distinctions between the MIS-4/3 transition and T1. Most important, the difference in sea level (MIS-4: $95 \mathrm{~m}$ below present; MIS-2/LGM: $120 \mathrm{~m}$ ) indicates that the MIS-4 northern ice sheets were at about $80 \%$ of their LGM volume. While Earth's orbital configuration and atmospheric $\mathrm{CO}_{2}$ concentrations for both the LGM and MIS-4 cold peaks were comparable, the rates of change during the MIS4/3 transition in atmospheric $\mathrm{CO}_{2}$ (MIS-4/3: 8 ppmV/ka (Bereiter et al., 2012); T1: 15 ppmV/ka (Monnin et al., 2001)), and also in Antarctic temperature (MIS-4/3: $\sim 0.75^{\circ} \mathrm{C} / \mathrm{ka}$; T1: $\sim 1.5^{\circ} \mathrm{C} / \mathrm{ka}$; Jouzel et al. (2007)), were only about half of that during T1. The ITCZ did not quite reach the southernmost position that it held towards the end of HS-1 (Deplazes et al., 2013). Weakening of the monsoon intensity was less severe during HS- 6 relative to HS- 1 and the abrupt monsoon intensification at the end of HS- 6 was smaller than that after HS-1 (Wang et al., 2001). SO sea ice retreat was substantial through HS-1, but minimal during the MIS-4/3 transition/ HS-6 (Wolff et al., 2006). Finally, there is no clear evidence for warming/destratification of the deepest Southern Ocean during the MIS-4/3 transition as occurred during T1 (Adkins, 2013).

We propose that these differences between the MIS-4 Southern Glacial Maximum and its Unfinished Termination and the MIS-2 LGM and T1 provide support for the view that the maximum size of the northern ice-sheets has been a necessary condition for terminations (Denton and Hughes, 1981; Raymo, 1997; Clark et al., 2009; Abe-Ouchi et al., 2013). Only the destabilization and melting of maximum size northern ice sheets (Denton and Hughes, 1981) triggered high-intensity HS (Denton et al., 2010) with farfield effects that were essential to transition global climate from glacial to sustained interglacial conditions, including the SO destratification (for example Sigman et al. (2010)) and the related increase in SO upwelling and $\mathrm{CO}_{2}$ release to the atmosphere (Anderson et al., 2009). By this argument, our study is not consistent with the scenarios making the case for regional southern forcing of terminations (Vandergoes et al., 2005) without northern control (Wolff et al., 2009).

Beyond the specific termination dynamics, the robust observation is that of a full glacial maximum of the Southern Hemisphere during MIS-4, and the onset of a termination that did not manage to bring the earth's climate out of the ice-age into a sustained interglacial state.

\section{Conclusions}

The Southern Hemisphere was in full-glacial configuration twice during the last glacial cycle, in both cases a termination began right after reaching the glacial culmination, that was paralleled by a HS in the North Atlantic region. This expands the polar ice-core 

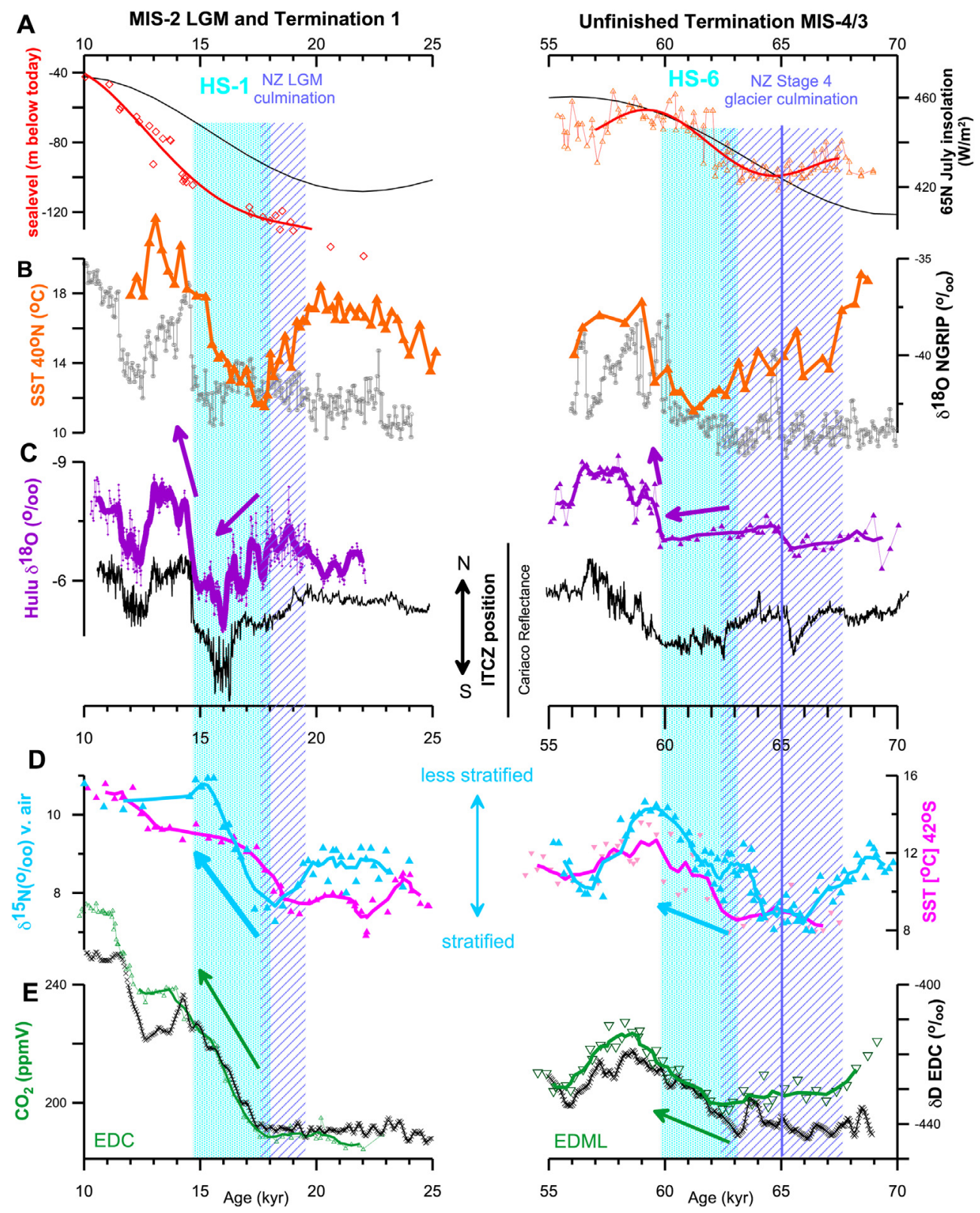

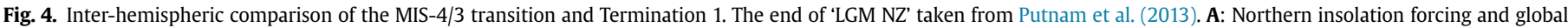

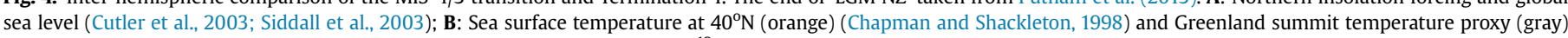

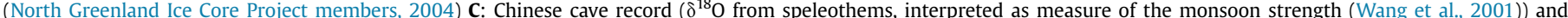

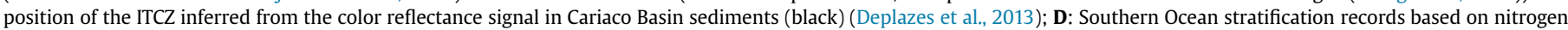

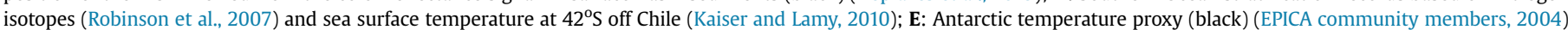

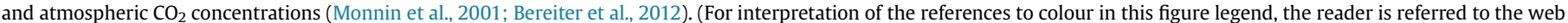
version of this article.)

based observation that warming events in Antarctica tend to be in phase with stadials in the Greenland ice core record (for example, Barbante et al. (2006)), and strengthens the evidence that New Zealand's temperature-sensitive mountain glaciers culminated during Antarctic cold periods (Kelley et al., 2014).

This study provides a basis for estimating first-order time-scales for the hemispheres to reach full-glacial configuration. Starting from the near-interglacial conditions of MIS-5a about 80,000 years ago (Simms et al., 2009; Dorale et al., 2010), 15 ka were sufficient for the marine-dominated Southern Hemisphere to approach full glacial configuration. The Northern Hemisphere and its continental ice-sheets reached only about $80 \%$ of the full-glacial state during this $15 \mathrm{ka}$ interval. After the MIS-4/3 transition, $60 \mathrm{ka}$ ago, about $50 \%$ of the maximum northern ice sheets were left on the continents. Subsequently, almost 40 ka of cooling grew the northern ice sheets from half to full glacial LGM size.

As a final observation, we note that major inter-termination transitions similar to the Unfinished Termination of the MIS-4 Southern Glacial Maximum were characteristic for glacial cycles exceeding 100,000 years in duration (EPICA community members, 2004; Lisiecki and Raymo, 2005). In contrast, about 425 ka ago, a shorter glacial cycle began subsequent to the MIS-11 interglacial, characterized by a quasi-steady cooling over some 55,000 years towards the full glacial MIS-10 peak $340 \mathrm{ka}$ ago that was followed 
by Termination 4 . The proposed concept of Southern Glacial Maxima and their Unfinished Terminations might thus help to explain the different durations of glacial cycles in the $100 \mathrm{ka}$ world.

\section{Acknowledgments}

Schaefer acknowledges support for this study by the National Science Foundation (EAR-P2C2 and GLD), NOAA, the Comer Science and Educational Foundation and the Lamont Climate Center. NOAA supported participation of Denton. Barrell was supported by the New Zealand Government through GNS Science's Global Change through Time research program. Schluechter's fieldwork was funded by Swiss Nationalfonds projects 21-043469.95/1 and 200020118038. Putnam was supported by CSEF, NOAA, and a Lamont Postdoctoral Fellowship. We thank Marcus Vandergoes for assistance during field-work and help in organizing sampling permits and Roberta Preston, Rhoborough Downs, for her assistance during the field campaigns, in particular at Star Hill. T. Wall (Simons Pass Station), J. Murray (The Wolds Station), T.J. and G. Wills (Irishman Creek Station), and J. and H. Mackenzie (Braemar Station) graciously permitted access to their properties. This is LDEO publication \#7877.

\section{Appendix A. Supplementary data}

Supplementary data related to this article can be found at http:// dx.doi.org/doi:10.1016/j.quascirev.2015.02.009.

\section{References}

Abe-Ouchi, A., Saito, F., Kawamura, K., Raymo, M.E., Okuno, J.i., Takahashi, K. Blatter, H., 2013. Insolation-driven 100,000-year glacial cycles and hysteresis of ice-sheet volume. Nature 500, 190-194.

Adkins, J.F., 2013. The role of deep ocean circulation in setting glacial climates Palaeoceanography 28. http://dx.doi.org/10.1002/palo.20046.

Anderson, B., Lawson, W., Owens, I., Goodsell, B., 2006. Past and future mass balance of Ka Roimata o Hine Hukatere (Franz Josef Glacier). J. Glaciol. 52, 597-608.

Anderson, B., Mackintosh, A., 2006. Temperature change is the major driver of lateglacial and Holocene glacier fluctuations in New Zealand. Geology 34, 121-124.

Anderson, B., Mackintosh, A., Stumm, D., George, L., Kerr, T., Winter-Billington, A., Fitzsimons, S., 2010. Climate sensitivity of a high-precipitation glacier in New Zealand. J. Glaciol. 56, 114-128.

Anderson, R.F., Ali, S., Bradtmiller, L.I., Nielsen, S.H.H., Fleisher, M.Q., Anderson, B.E. Burckle, L.H., 2009. Wind-driven upwelling in the Southern Ocean and the deglacial rise in atmospheric $\mathrm{CO}_{2}$. Science 23, 1443-1448.

Balco, G., Stone, J.O., Lifton, N.A., Dunai, T.J., 2008. A complete and easily accessible means of calculating surface exposure ages or erosion rates from $\mathrm{Be}-10$ and $\mathrm{Al}$ 26 measurements. Quat. Geochronol. 3, 174-195.

Barbante, C., Barnola, J.M., Becagli, S., Beer, J., Bigler, M., 2006. One-to-one coupling of glacial climate variability in Greenland and Antarctica. Nature 444, 195-198.

Barker, S., Diz, P., 2014. Timing of the descent into the last Ice Age determined by the bipolar seesaw. Paleoceanography 29, 489-507.

Barker, S., Diz, P., Vautravers, M.J., Pike, J., Knorr, G., 2009. Interhemispheric Atlantic seesaw response during the last deglaciation. Nature 457, 1097-1102.

Barrell, D.J.A., 2014. The Balmoral moraines near Lake Pukaki, Southern Alps: a new reference area for the early Otira Glaciation in New Zealand. N. Z. J. Geol. Geophys. 57, 442-452.

Bereiter, B., Lüthi, D., Siegrist, M., Schüpbach, S., Stocker, T.F., Fischer, H., 2012. Mode change of millennial $\mathrm{CO}_{2}$ variability during the last glacial cycle associated with a bipolar marine carbon seesaw. Proc. Natl. Acad. Sci. 109, 9755-9760.

Burrows, C.J., 2005. Julius Haast in the Southern Alps. Canterbury University Press, Christchurch, New Zealand, p. 215.

Chapman, M.R., Shackleton, N.J., 1998. Millennial-scale fluctuations in North Atlantic heat flux during the last 150,000 years. Earth Planet. Sci. Lett. 159, $57-70$.

Cheng, H., Edwards, R.L., Broecker, W.S., Denton, G.H., Kong, X.G., Wang, Y.J. Zhang, R., Wang, X.F., 2009. Ice age terminations. Science 326, 248-252.

Clark, P.U., Dyke, A.S., Shakun, J.D., Carlson, A.E., Clark, J., Wohlfarth, B., Mitrovica, J.X., Hostetler, S.W., McCabe, A.M., 2009. The Last Glacial Maximum. Science 325, 710-714.

Cutler, K.B., Edwards, R.L., Taylor, F.W., Cheng, H., Adkins, J., Gallup, C.D., Cutler, P.M. Burr, G.S., Bloom, A.L., 2003. Rapid sea-level fall and deep-ocean temperature change since the last interglacial period. Earth Planet. Sci. Lett. 206, 253-271.

Denton, G.H., Anderson, R.F., Toggweiler, J.R., Edwards, R.L., Schaefer, J.M. Putnam, A., 2010. The last glacial termination. Science 328, 1652-1656.
Denton, G.H., Hughes, T.J., 1981. The Last Great Ice Sheets. Wiley, p. 484.

Deplazes, G., Luckge, A., Peterson, L.C., Timmermann, A., Hamann, Y., Hughen, K.A. Rohl, U., Laj, C., Cane, M.A., Sigman, D.M., Haug, G.H., 2013. Links between tropical rainfall and North Atlantic climate during the last glacial period. Nat. Geosci. 6, 213-217.

Dorale, J.A., Onac, B.P., Fornós, J.J., Ginés, J., Ginés, A., Tuccimei, P., Peate, D.W., 2010. Sea-level highstand 81,000 years ago in Mallorca. Science 327, 860-863.

Drost, F., Renwick, J., Bhaskaran, B., Oliver, H., McGregor, J., 2007. A simulation of New Zealand's climate during the Last Glacial Maximum. Quat. Sci. Rev. 26, 2505-2525.

Elderfield, H., Greaves, M., Barker, S., Hall, I.R., Tripati, A., Ferretti, P., Crowhurst, S., Booth, L., Daunt, C., 2010. A record of bottom water temperature and seawater $\delta^{18} \mathrm{O}$ for the Southern Ocean over the past $440 \mathrm{kyr}$ based on $\mathrm{Mg} / \mathrm{Ca}$ of benthic foraminiferal Uvigerina spp. Quat. Sci. Rev. 29, 160-169.

EPICA community members, 2004. Eight glacial cycles from an Antarctic ice core. Nature 429, 623-628.

Fastook, J.L., Head, J.W., Marchant, D.R., Forget, F., 2008. Tropical mountain glaciers on Mars: altitude-dependence of ice accumulation, accumulation conditions, formation times, glacier dynamics, and implications for planetary spin-axis orbital history, Icarus 198, 305-317.

Fastook, J.L., Prentice, M., 1994. A finite-element model of Antarctica: sensitivity test for meteorological mass-balance relationship. J. Glaciol. 40, 161-175.

Golledge, N.R., Mackintosh, A.N., Anderson, B.M., Buckley, K.M., Doughty, A.M., Barrell, D.J.A., Denton, G.H., Vandergoes, M.J., Andersen, B.G., Schaefer, J.M., 2012. Last Glacial Maximum climate in New Zealand inferred from a modelled Southern Alps icefield. Quat. Sci. Rev. 46, 30-45.

Hijmans, R., Cameron, S.E., Parra, J.L., Jones, P.G., Jarvis, A., 2005. Very high resolution interpolated climate surfaces for global land areas. Int. J. Climatol. 25, 1965-1978.

Huybers, P., Wunsch, C., 2005. Obliquity pacing of the late Pleistocene glacial terminations. Nature 434, 491-494.

Jouzel, J., Masson-Delmotte, V., Cattani, O., Dreyfus, G., Falourd, S., Hoffmann, G., Minster, B., Nouet, J., Barnola, J.M., Chappellaz, J., Fischer, H., Gallet, J.C., Johnsen, S., Leuenberger, M., Loulergue, L., Luethi, D., Oerter, H., Parrenin, F., Raisbeck, G., Raynaud, D., Schilt, A., Schwander, J., Selmo, E., Souchez, R., Spahni, R., Stauffer, B., Steffensen, J.P., Stenni, B., Stocker, T.F., Tison, J.L., Werner, M., Wolff, E.W., 2007. Orbital and millennial Antarctic climate variability over the past 800,000 years. Science 317, 793-796.

Kaiser, J., Lamy, F., 2010. Links between Patagonian Ice Sheet fluctuations and Antarctic dust variability during the last glacial period (MIS 4-2). Quat. Sci. Rev. 29, 1464-1471.

Kelley, S.E., Kaplan, M.R., Schaefer, J.M., Andersen, B.G., Barrell, D.J.A., Putnam, A.E., Denton, G.H., Schwartz, R., Finkel, R.C., Doughty, A.M., 2014. High-precision 10Be chronology of moraines in the Southern Alps indicates synchronous cooling in Antarctica and New Zealand 42,000 years ago. Earth Planet. Sci. Lett. 405, 194-206.

Lal, D., 1991. Cosmic ray labeling of erosion surfaces: in situ nuclide production rates and erosion models. Earth Planet. Sci. Lett. 104, 424-439.

Lambert, F., Delmonte, B., Petit, J.R., Bigler, M., Kaufmann, P.R., Hutterli, M.A., Stocker, T.F., Ruth, U., Steffensen, J.P., Maggi, V., 2008. Dust-climate couplings over the past 800,000 years from the EPICA Dome C ice core. Nature 452, 616-619.

Lisiecki, L.E., Raymo, M.E., 2005. A Pliocene-Pleistocene stack of 57 globally distributed benthic delta O-18 records. Paleoceanography 20. http://dx.doi.org/ 10.1029/2004pa001071.

Martinez-Garcia, A., Rosell-Mele, A., Jaccard, S.L., Geibert, W., Sigman, D.M. Haug, G.H., 2011. Southern Ocean dust-climate coupling over the past four million years. Nature 476, 312-316.

Masarik, J., Frank, M., Schäfer, J.M., Wieler, R., 2001. Correction of in situ cosmogenic nuclide production rates for geomagnetic field intensity variations during the past 800,000 years. Geochim. Cosmochim. Acta 65, 2995-3003.

Monnin, E., Indermuehle, A., Daellenbach, A., Flueckiger, J., Stauffer, B., Stocker, T.F., Raynaud, D., Barnola, J.-M., 2001. Atmospheric $\mathrm{CO}_{2}$ concentrations over the Last Glacial Termination. Science 291, 112-114.

Ninnemann, U.S., Charles, C.D., 1997. Regional differences in Quaternary Subantarctic nutrient cycling: link to intermediate and deep water ventilation. Paleoceanography $12,560-567$.

North Greenland Ice Core Project members, 2004. High-resolution record of Northern Hemisphere climate extending into the last interglacial period. Nature 431, 147-151.

Norton, D., 1985. A multivariate technique for estimating New Zealand temperature normals. Weather Clim. 5, 64-74.

Oerlemans, J., 2005. Extracting a climate signal from 169 glacier records. Science 308, 675-677.

Pahnke, K., Sachs, J.P., 2006. Sea surface temperatures of southern midlatitudes 0-160 kyr B.P. Paleoceanography 21, PA2003.

Porter, S.C., 1975. Equilibrium-line altitudes of late Quaternary glaciers in the Southern Alps, New Zealand. Quat. Res. 5, 27-47.

Putnam, A.E., Schaefer, J.M., Barrell, D., Kaplan, M., Denton, G.H., Vandergoes, M., Schwartz, R., Finkel, R.C., Goehring, B., Kelley, S.M., 2010. In situ cosmogenic ${ }^{10} \mathrm{Be}$ production-rate calibration from the Southern Alps, New Zealand. Quat. Geochronol. 5, 392-409.

Putnam, A.E., Schaefer, J.M., Denton, G.H., Barrell, D.J.A., Birkel, S.D., Andersen, B.G., Kaplan, M.R., Finkel, R.C. Schwartz, R. Doughty, A.M., 2013. The Last Glacial Maximum at $44^{\circ} \mathrm{S}$ documented by a ${ }^{10} \mathrm{Be}$ moraine chronology at Lake Ohau, Southern Alps of New Zealand. Quat. Sci. Rev. 62, 114-141. 
Raymo, M.E., 1997. The timing of major climate terminations. Palaeoceanography $12,577-585$.

Robinson, R.S., Mix, A., Martinez, P., 2007. Southern Ocean control on the extent of denitrification in the southeast Pacific over the last 70 ka. Quat. Sci. Rev. 26, $201-212$.

Schaefer, J.M., Denton, G.H., Barrell, D.J.A., Ivy-Ochs, S., Kubik, P.W., Andersen, B.G., Phillips, F., Lowell, T.V., Schluechter, C., 2006. Near-synchronous interhemispheric termination of the Last Glacial Maximum in mid-latitudes. Science 312, 1510-1513.

Schaefer, J.M., Denton, G.H., Kaplan, M., Putnam, A., Finkel, R.C., Barrell, D.J.A Andersen, B.G., Schwartz, R., Mackintosh, A., Chinn, T., Schlüchter, C., 2009. High frequency Holocene glacier fluctuations in New Zealand differ from the northern signature. Science 324, 622.

Siddall, M., Rohling, E.J., Almogi-Labin, A., Heimleben, C., Meischner, D., Schmelzer, I., Smeed, D.A., 2003. Sea-level fluctuations during the last glacial cycle. Nature 423, 853-857.

Sigman, D.M., Hain, M.P., Haug, G.H., 2010. The polar ocean and glacial cycles in atmospheric $\mathrm{CO}_{2}$ concentration. Nature 466, 47-55.

Simms, A.R., DeWitt, R., Rodriguez, A.B., Lambeck, K., Anderson, J.B., 2009. Revisiting marine isotope stage 3 and 5a (MIS3-5a) sea levels within the northwestern Gulf of Mexico. Glob. Planet. Change 66, 100-111.

Stone, J., 2000. Air pressure and cosmogenic isotope production. J. Geophys. Res. $105,23753-23759$.

Sugden, D.E., McCulloch, R.D., Bory, A.J.M., Hein, A.S., 2009. Influence of Patagonian glaciers on Antarctic dust deposition during the last glacial period. Nat. Geosci. 2, 281-285.
Vandergoes, M.J., Newnham, R.M., Preusser, F., Hendy, C.H., Lowell, T.V., Fitzsimons, S.J., Hogg, A.G., Kasper, H.U., Schluchter, C., 2005. Regional insolation forcing of late Quaternary climate change in the Southern Hemisphere. Nature 436, 242-245.

WAIS Divide Project Members, 2013. Onset of deglacial warming in West Antarctica driven by local orbital forcing. Nature 500, 440-444.

Wang, Y.J., Cheng, H., Edwards, R.L., An, Z.S., Wu, J.Y., Shen, C.-C., Dorale, J.A., 2001 A high-resolution absolute-dated Late Pleistocene Monsoon Record from Hulu Cave, China. Science 294, 2345-2348.

Williams, P.W., McGlone, M., Neil, H., Zhao, J.-X., 2015. A review of New Zealand paleoclimate from the Last Interglacial to the global Last Glacial Maximum. Quat. Sci. Rev. 110, 92-106.

Winckler, G., Anderson, R.F., Fleisher, M.Q., McGee, D., Mahowald, N., 2008. Covariant Glacial-Interglacial dust fluxes in the Equatorial Pacific and Antarctica. Science 320, 93-96.

Wolff, E.W., Fischer, H., Fundel, F., Ruth, U., Twarloh, B., Littot, G.C., Mulvaney, R. Rothlisberger, R., de Angelis, M., Boutron, C.F., Hansson, M., Jonsell, U. Hutterli, M.A., Lambert, F., Kaufmann, P., Stauffer, B., Stocker, T.F., Steffensen, J.P., Bigler, M., Siggaard-Andersen, M.L., Udisti, R., Becagli, S., Castellano, E. Severi, M., Wagenbach, D., Barbante, C., Gabrielli, P., Gaspari, V., 2006. Southern Ocean sea-ice extent, productivity and iron flux over the past eight glacial cycles. Nature 440, 491-496.

Wolff, E.W., Fischer, H., Rothlisberger, R., 2009. Glacial terminations as southern warmings without northern control. Nat. Geosci. 2, 206-209. 